\title{
Four new species, a new synonymy and new record for Thraulodes Ulmer 1920 (Ephemeroptera: Leptophlebiidae: Atalophlebiinae)
}

\author{
Rodolfo Mariano $^{1 *}$, R. Wills Flowers ${ }^{2}$ and Claudio G. Froehlich ${ }^{3}$ \\ ${ }^{1}$ Universidade Estadual de Santa Cruz-UESC, Departamento de Ciências Agrárias e Ambientais, Rodovia Ilhéus-Itabuna, km 16, \\ Ilhéus, BA, Brazil \\ 2 Center for Biological Control, Florida A\&M University, Tallahassee, FL 32307, USA \\ ${ }^{3}$ Universidade de São Paulo-USP, Faculdade de Filosofia, Ciências e Letras de Ribeirão Preto, Departamento de Biologia, \\ Laboratório de Entomologia Aquática, Monte Alegre, Ribeirão Preto, SP, Brazil
}

\begin{abstract}
Four new species of Thraulodes Ulmer (Ephemeroptera: Leptophlebiidae), Thraulodes amanda sp. n., Thraulodes pelicanus sp. n., Thraulodes xavantinensis sp. n. and Thraulodes sinuosus sp. n are described based on imagos. A new synonymy (Thraulodes lepidus [Ulmer]=Thraulodes cryptodrilus Nieto \& Domínguez) is proposed and the distribution of Thraulodes schlingeri is expanded based on a new record from western Brazil.
\end{abstract}

Key words: Neotropical / Ephemeroptera / Leptophlebiidae / Imago / Thraulodes

\section{Introduction}

The genus Thraulodes was established by Ulmer (1920a) for the type species Thraulus laetus described from imagos of Colombia by Eaton (1884) and provisionally placed in Calliarcys Eaton (1881). Many species have been described since then, and presently there are about 50 known species of Neotropical Thraulodes. Almost half of these species have the nymph undescribed. This is a problem found in many groups, most of the time because of the impossibility of returning to the place where the specimens were collected. The first complete key for the genus was proposed by Traver and Edmunds in 1967, a revision of Thraulodes that included descriptions of 11 new species and discussions on features of imagos, nymphs and characters of ova. In 2006, Domínguez et al. made a compilation of the South American species of Ephemeroptera, including a new key for the Thraulodes species.

Until now only eight species occur in Brazil: Thraulodes daidaleus Thew, 1960, Thraulodes ulmeri Edmunds, 1950, Thraulodes itatiajanus Traver \& Edmunds, 1967, Thraulodes jones Gonçalvez et al., 2010, Thraulodes limbatus Navás (1936), Thraulodes subfasciata Navás, 1934, Thraulodes traverae Thew, 1960 and Thraulodes schlingeri Traver \& Edmunds, 1967, and there is 11 species for Costa Rica: Thraulodes brunneus Koss, 1966, Thraulodes centralis Traver, 1946, Thraulodes hilaris (Eaton), 1892, Thraulodes hilaroides Traver, 1946, Thraulodes irretitus Navás, 1924,

\footnotetext{
*Corresponding author: rodolfomls@gmail.com
}

Thraulodes lepidus (Eaton), 1884, Thraulodes packeri Traver \& Edmunds, 1967, Thraulodes prolongatus Traver, 1946, Thraulodes spangleri Traver \& Edmunds, 1967, Thraulodes valens (Eaton), 1892 and Thraulodes zonalis Traver \& Edmunds, 1967.

The aim of this paper is to describe four new species of Thraulodes based on imagos, three species from Brazil and one from Costa Rica; a new synonymy is presented.

\section{Materials and methods}

The material used in this study is preserved in ethyl alcohol 80\%. Male legs and genitalia were dissected and mounted in Canada Balsam. Wings were mounted dry. The material is deposited in the following institutions: Museum of Zoology, University of São Paulo, São Paulo, Brazil (MZSP); Florida A\&M University, Tallahassee, Florida, USA (FAMU) and Museum of Zoology-UFBA, Salvador, Bahia, Brazil (MZFBA).

\section{Taxonomy}

\section{New record for Brazil, State of Acre}

T. schlingeri Traver \& Edmunds 1967

Material examined: Imagos, Brazil, Mâncio LimaAC, Parque Nacional da Serra do Divisor, Rio Azul, 15.III.2006, light trap, A.R. Calor. 

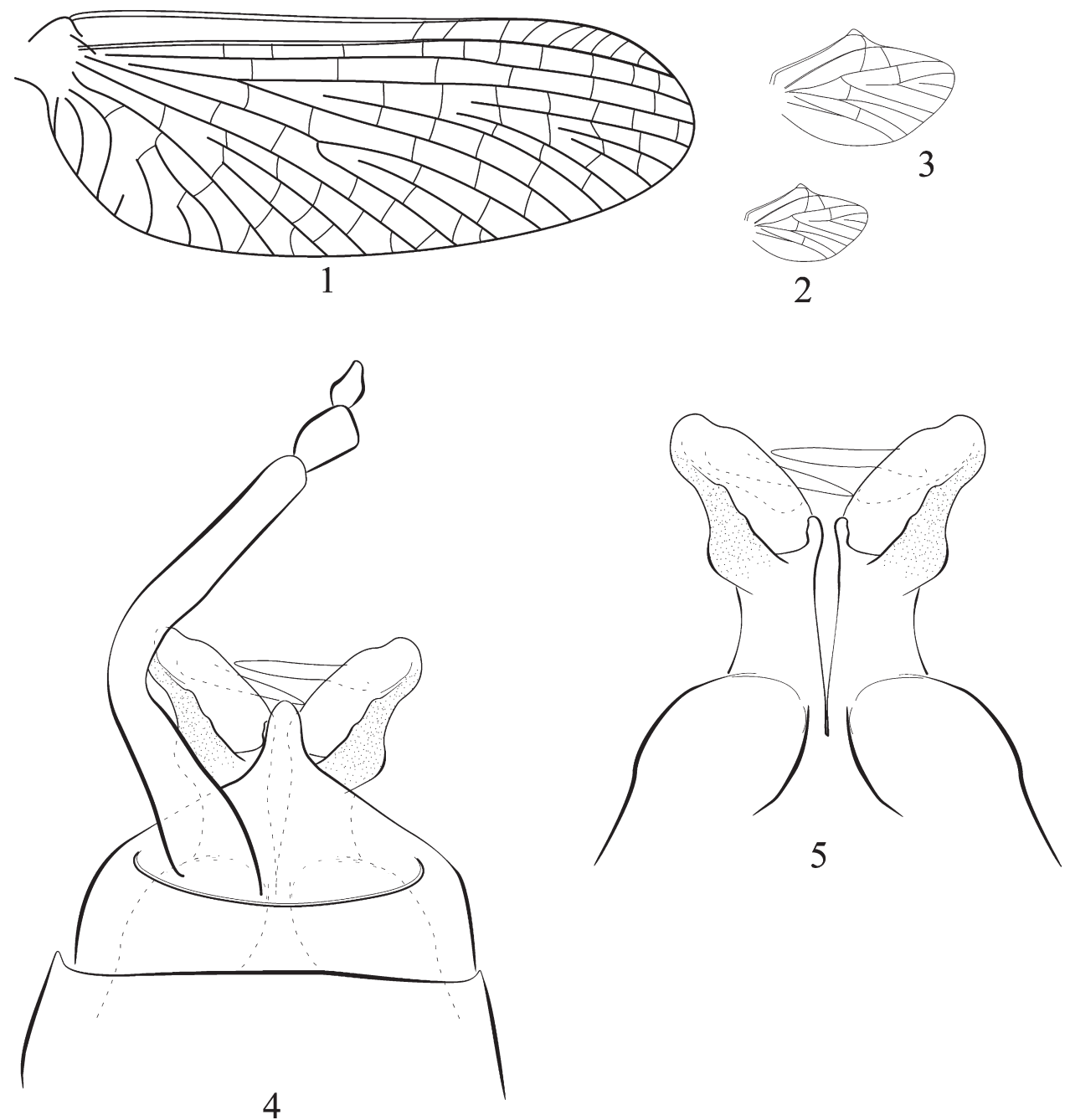

Figs. 1-5. Thraulodes xavantinensis: 1. Forewing. 2. Hind wing. 3. Hind wing (enlarged). 4. Styliger plate (ventral view). 5. Penes (ventral view).

\section{New synonymy}

T. lepidus (Eaton, 1884).

T. lepidus Eaton, 1884:109.

T. lepidus; Ulmer, 1920a:34; 1920b:116; Kimmins, 1934:343; Traver \& Edmunds, 1967:369 (= Thraulodes pedregoso).

Thraulodes lepida [sic]; Ulmer, 1943:22.

T. pedregoso Traver, 1946:430.

Thraulodes cryptodrilus Nieto \& Domínguez, 2001:63.

\section{New Synonym.}

After analyzing the holotype and paratypes of T. lepidus and T. cryptodrilus, we conclude that the species described by Nieto and Domínguez (2001) based on material from México collected in 1981 is the same as T. lepidus, and is proposed here as a synonym.

\section{Descriptions}

Thraulodes xavantinensis sp. n. Mariano \& Froehlich (Figs. 1-5 and 22).
Male imago. Length: body, $6.4 \mathrm{~mm}$; forewings, $4.9 \mathrm{~mm}$; hind wings, $0.8 \mathrm{~mm}$; general coloration brown. Head: dark brown; antenna pale with scape brown; upper portion of eyes yellowish brown, lower portion black; ocelli white with a black ring at base. Thorax: general color of pronotum, mesonotum and metanotum light chestnut. Pronotum with a medial dark macula. Mesonotum and metanotum with sutures yellowish brown. Prosternum whitish; mesosternum whitish with furcasternum chestnut. Wings (Figs. 1 and 3): forewings hyaline; costal and subcostal zones translucent; costal membrane basal to bulla without cross veins and 9 cross veins distal to bulla. Hind wings hyaline with 6 cross veins. Legs: legs with femur light yellowish, apical 1/3 of femur with a brownish band followed by a black band and a blackish macula in the median region; tibiae whitish with base yellowish brown; tarsi whitish. Abdomen (Fig. 22): terga in dorsal view predominantly brown, in lateral view translucent; tergum I brown washed with black on anterior margin and median area; tergum II brown with a anterior pale band and a subanterior dark area medially; terga III-VI brown, anterior region with a light band; two dark spots on 

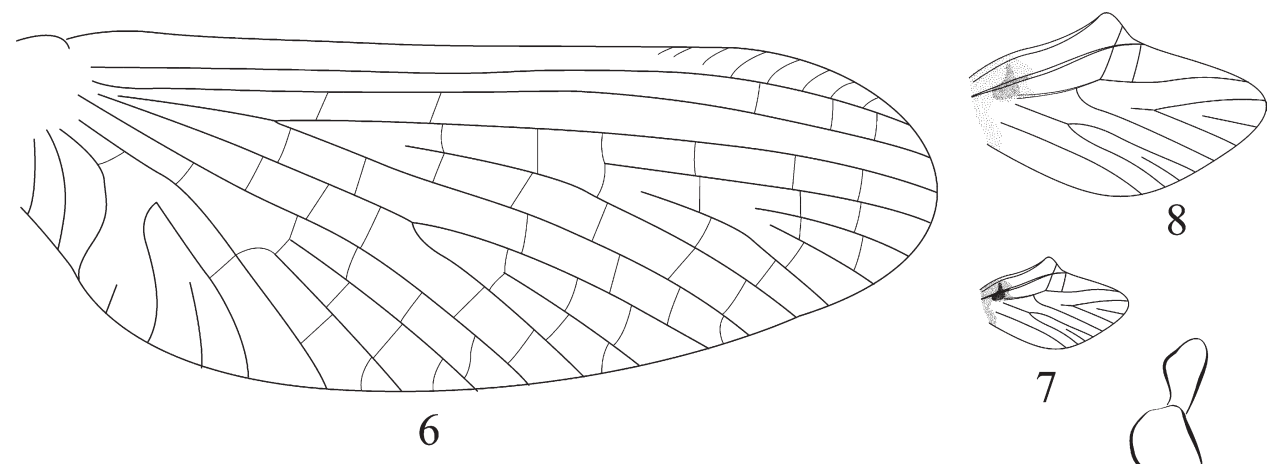

8
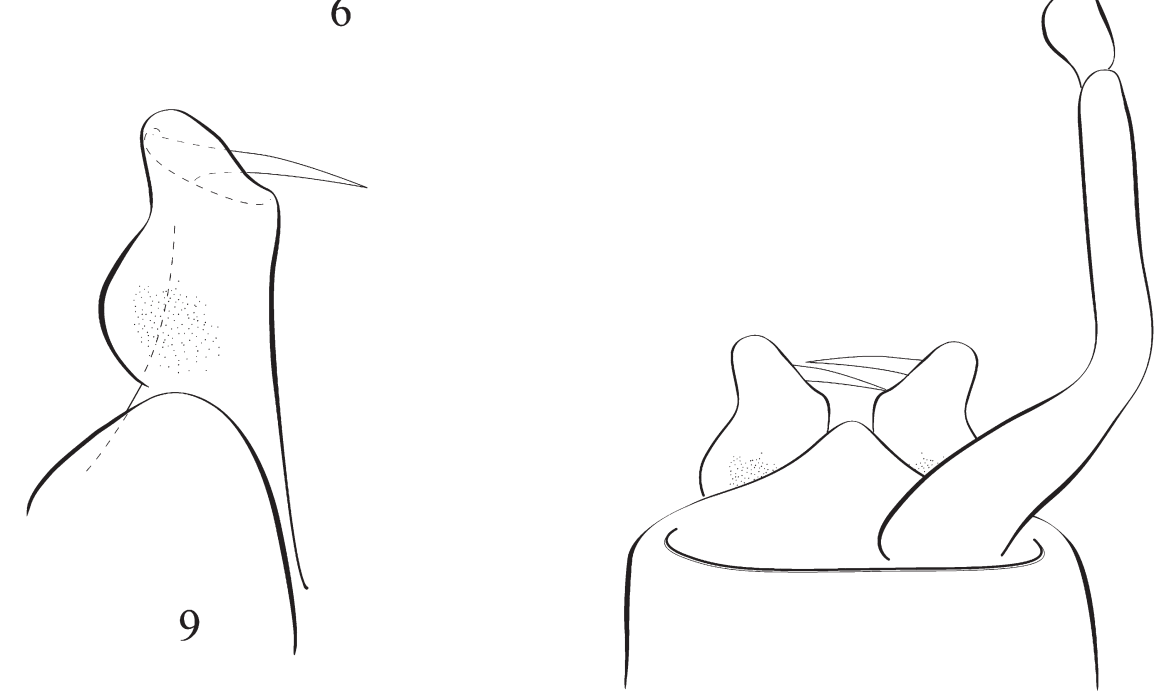

10

Figs. 6-10. Thraulodes amanda: 6. Forewing. 7. Hind wing. 8. Hind wing (enlarged). 9. Penes (ventral view). 10. Styliger plate (ventral view).

medial region and dark bands on lateral region; terga VI with a dark band on posterior region; terga VII-VIII brown with median region light and with posterior black band; terga IX-X light brown. Sterna I-X translucent whitish. Genitalia (Figs. 4 and 5): forceps yellowish, segments II-III washed with black. Penes yellowish washed with black on ventral lateral region; penes $2 / 3$ divided apically, with a pair of long and narrow spines; apicolateral area forming an "ear"; external margin forming lateral pouch and with recurved folds parallel to inner margin. Terminal filament broken off and missing.

Female and nymph. Unknown.

Type material. ô Holotype: (MZSP) male imago, Brazil, Nova Xavantina-MT, Fazenda Jerusalém, Cachoeira, 05-xii-2006, Calor, A.R.; Mariano, R. and Mateus, S. Paratypes: (MZFBA) 1 $\sigma^{\uparrow}$ imago and 6 ô subimagos, Brazil, Nova Xavantina - MT, córrego de Ponte de Pedra, 06-xii2006, Calor, A.R.; Mariano, R. and Mateus, S.

Etymology. After the type locality, Nova Xavantina.

Diagnosis. This species can be separated from all the other congeners by the combination of the following characters: (1) costal membrane of forewing basal to bulla without cross veins; (2) costal and subcostal zones of forewing translucent; (3) one band on femora; (4) terga predominantly brown; (5) spines of penes long and narrow; apicolateral area forming a "ear"; external margin forming lateral pouch and with recurved folds parallel to inner margin. This species will key to Thraulodes regulus in Domínguez et al. (2006).

Thraulodes amanda sp. n. Mariano \& Froehlich (Figs. 6-10, 23 and 24).

Male imago. Length: body, $6.0 \mathrm{~mm}$, forewing: $5.2 \mathrm{~mm}$; hind wings: $1.2 \mathrm{~mm}$. General color: brown. Head: brown, antennae light brown, with scape and pedicel brown; upper portion of eyes chestnut, lower portion black; ocelli white with basal black rings. Thorax: general color of pronotum, mesonotum and metanotum light chestnut. Pronotum with dark maculae; mesonotum and metanotum with suture yellowish brown. Prosternum pale white with two brown bands; mesosternum with furcasternum chestnut. Wings (Figs. 6-8): forewings hyaline, costal and subcostal of the fore wing translucent; costal membrane basal to bulla without cross veins and 8-10 cross veins distal to bulla; hind wings hyaline with a dark spot at base, with 3-4 cross veins. Legs: femora of foreleg yellowish with an apical brown macula followed by a dark band, a brown reddish macula on $1 / 2$ from base; tibiae and tarsomeres yellowish. Femora of median and hind legs yellowish with two brown reddish spots, one apical with a black band on base and one spot located $1 / 2$ from base. 


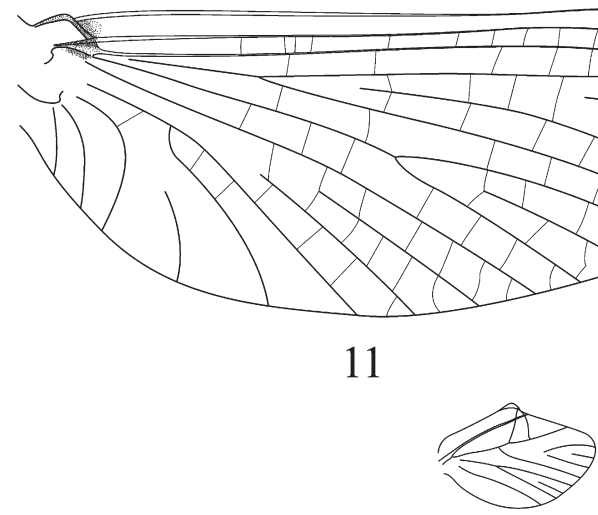

12

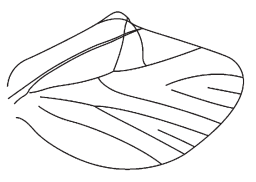

13

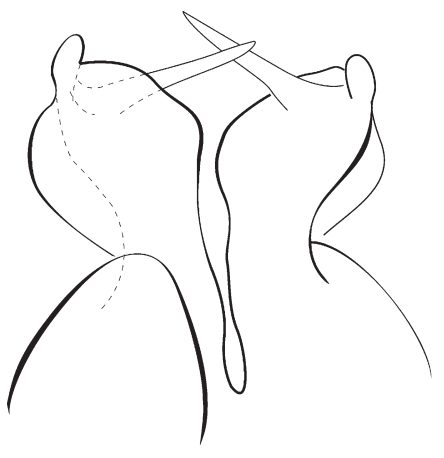

14

Figs. 11-15. Thraulodes pelicanus: 11. Forewing. 12. Hind wing. 13. Hind wing (enlarged). 14. Penes (left ventral view, right dorsal view). 15. Styliger plate (ventral view).

Tarsi of median and hind legs yellowish with base brownish. Abdomen (Fig. 23): brown, terga I-VI with two anterolateral black spots; terga I-VII with a reddish spot on posterior region; terga IV-VI with an anterior translucid area; lateral view of terga and sterna with a median and antero bands translucent; terga VII-X brown with posterior region reddish; sterna translucent with dark side. Genitalia (Figs. 9 and 10): forceps yellowish. Penes (Fig. 9) yellowish with a red spot on ventral lateral region; penes $2 / 3$ divided apically, with a pair of long and narrow spines; apicolateral area not forming an "ear"; external margin forming lateral pouch and without recurved folds. Terminal filament broken off and missing.

Female imago. General color: brown. Wings and markings of head as in male; thorax as in male. Abdominal segments as in male except for the absence of the translucid areas of the entire abdomen and the general color pattern darker than in male (Fig. 24).

Nymph. Unknown.

Type material. $\widehat{o}$ Holotype: (MZSP) Brazil, Goiás State, Chapada dos Veadeiros, Ribeirão Água Fria, 16-xii-2006, Bispo, P.C.; Yokoyama, E. and Paciência, G. Paratypes: (MZFBA) ô same data as holotype. 02 Female same data as holotype.

Etymology. In memoriam of Amanda Lucas Gimeno, student and friend, who died tragically.
Diagnosis. This species can be separated from all the other congeners by a combination of the following characters: (1) costal membrane basal to bulla without cross veins; (2) costal and subcostal of the fore wing translucent; (3) two band on femora; (4) abdominal color pattern predominantly brown, terga I-VI with two anterolateral black spots; (5) spines of penes long and narrow; apicolateral area not forming a "ear"; external margin forming lateral pouch and without recurved folds. This species will key to T. regulus in Domínguez et al. (2006).

Thraulodes pelicanus sp. n. Mariano \& Froehlich (Figs. 11-15 and 25).

Male imago. Length: body, $9.3 \mathrm{~mm}$; forewings, $8.5 \mathrm{~mm}$; hind wings, $1.6 \mathrm{~mm}$; general coloration brown. Head: brown; antenna light brown with pedicel brown and scape pale; upper portion of eyes brown yellowish and lower portion black; ocelli white with a black ring at base. Thorax: general color of pronotum, mesonotum and metanotum chestnut with suture brown. Prosternum pale white; mesosternum with furcasternum dark brown. Wings (Figs. 11-13): forewings hyaline; costal and subcostal zones translucent; costal membrane basal to bulla without cross veins and 8 cross veins distal to bulla. Hind wings hyaline with 3-4 cross veins. Legs: all legs yellowish with $1 / 3$ of femora with apical brown band followed by a 


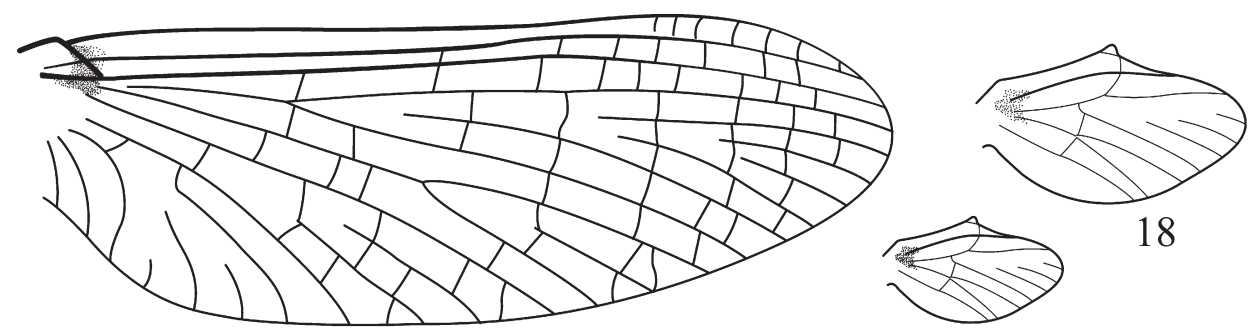

16

17
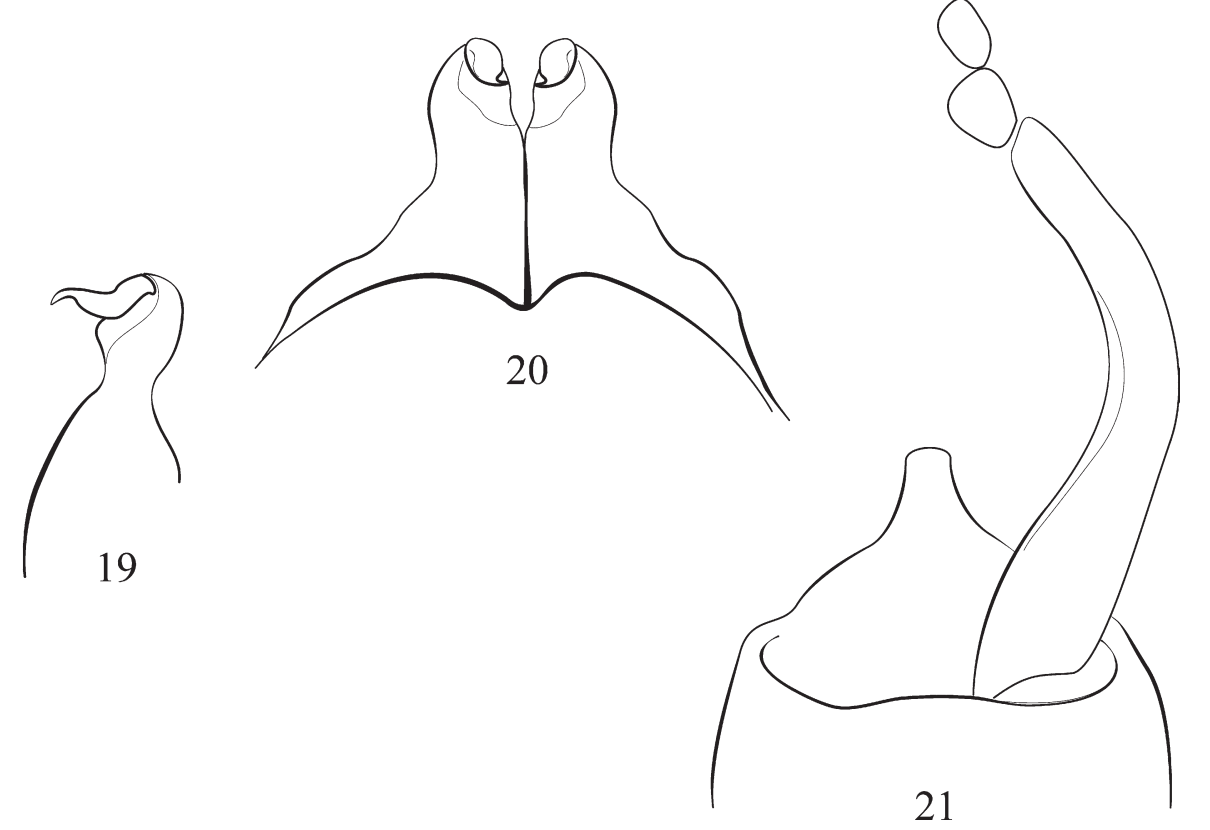

Figs. 16-21. Thraulodes sinuosus: 16. Forewing. 17. Hind wing. 18. Hind wing (enlarged). 19. Penes (lateral view). 20. Penes (ventral view). 21. Styliger plate (ventral view).

black band; tibiae and tarsomeres yellowish. Abdomen (Fig. 25): terga I-VI translucent; tergum I with a anterior brown band; terga II-VI with four black spots, two anterolateral and two medial; terga IV-VI with a narrow anterior and posterior transverse bands; terga VII-X brown yellowish; sterna I-X translucent whitish. Genitalia (Figs. 14 and 15): forceps yellowish. Penes (Fig. 14) yellowish; almost totally divided with a pair of long and narrow spines; apicolateral area forming an "ear"; external margin forming lateral pouch and without recurved folds parallel to inner margin. Terminal filament twice the total size of body, all segments white with base dark.

Female and nymph. Unknown.

Material. ô Holotype: (MZSP) Brazil, Iporanga-SP, Parque Estadual Intervales, Rio do Carmo, próximo ao Córrego Inferno, 29-xi-2002, Melo, A.S.; Blahnik, R. e Prather, A. Paratype: (MZFBA) ô same data as holotype. Etymology. The shape of the penes resembles the silhouette of a pelican.

Diagnosis. This species can be separated from all the other congeners by combination of the following characters: (1) costal membrane of forewings basal to bulla without cross veins; (2) costal and subcostal zones of forewings translucent; (3) two bands on femora; (4) terga I-VI translucent; (5) spines of penes long and narrow; apicolateral area forming an "ear"; external margin forming lateral pouch and without recurved folds. This species will key to Thraulodes marreroi and Thraulodes osiris in Domínguez et al. (2006).

Thraulodes sinuosus sp. n. Mariano \& Flowers (Figs. 16-21, 26 and 27).

Male imago. Length: body, $5.5 \mathrm{~mm}$; forewings, $6.7 \mathrm{~mm}$; hind wings, $1.3 \mathrm{~mm}$; general coloration translucent. Head: brown; antenna light brown with pedicel brown and scape pale; upper portion of eyes yellowish brown and lower portion black; ocelli white with a black ring at base. Thorax: general color of pronotum, mesonotum and metanotum brownish. Mesonotum and metanotum with sutures yellowish brown. Prosternum and mesosternum pale white.Wings (Figs. 16-18): forewings hyaline; costal and subcostal zones translucent; base with a dark spot; costal membrane basal to bulla without cross veins and 7 cross veins distal to bulla. Hind wings hyaline with 4 cross veins; base with a dark spot. Legs: all legs with femora light yellowish; apical $1 / 3$ of femur yellow followed by a black band. Tibia and tarsomeres white pale. Abdomen (Figs. 26 and 27): tergum I gray; terga II-VI translucent with two anterolateral dark spots; terga VII-X brown; 


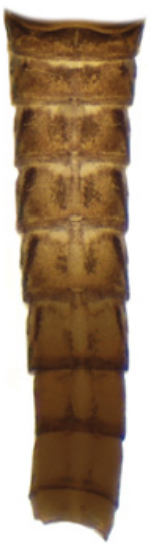

22

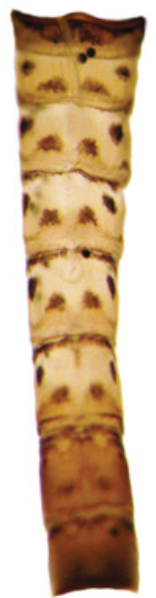

25

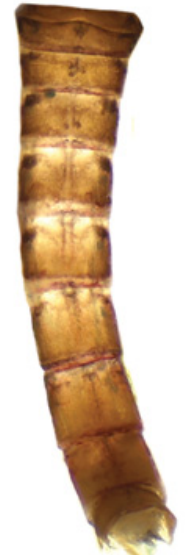

23

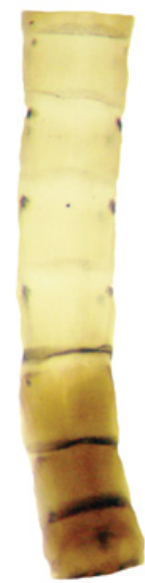

26

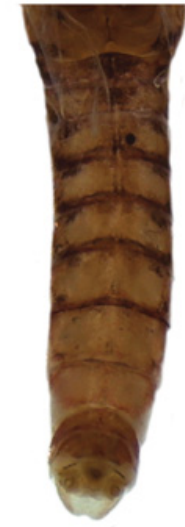

24

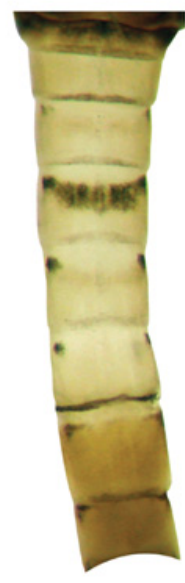

27
Figs. 22-27. Abdominal color pattern: 22. Thraulodes xavantinensis (terga I-IX). 23. Thraulodes amanda (male, terga I-IX). 24. T. amanda (female terga I-X). 25. Thraulodes pelicanus (terga I-VIII). 26. Thraulodes sinuosus (terga II-IX). 27. T. sinuosus (terga I-VIII).

terga VI-X with a black posterior band; sterna I-VI translucent; sterna VII-X brown; in some specimens the tergum IV with a blackish transverse band (Fig. 27). Genitalia (Figs. 19-21): forceps pale. Penes (Figs. 19 and 20) yellowish; totally divided with a pair of small and sinuous spines; apicolateral area not forming an "ear"; external margin not forming lateral pouch and without recurved folds. Terminal filament broken off and missing. Female and nymph. Unknown.

Type material. $\widehat{t}$ Holotype: Costa Rica, Puntarenas, Rio Guineal, 830 m, 22-xi-86, Holzenthal, Morse and Fasth. Paratypes: 今o, same data as holotype; ô Panama, Prov. Chiriqui, Fortuna, 14-xii-1977, Flowers, R. W.

Etymology. Sinuosus because of the shape of penes spine. Diagnosis. This species can be separated from all the other congeners by combination of the following characters: (1) costal membrane of forewings basal to bulla without cross veins; (2) costal and subcostal zones of forewings translucent; (3) one band on femora; (4) terga II-VI translucent, sometimes with a median transverse band; and (5) spines of penes small and sinuous; apicolateral area not forming an "ear"; external margin not forming lateral pouch and without recurved folds.

\section{Discussion}

T. pelicanus, T. amanda and T. xavantinensis from Brazil are easily distinguished from the other species based on the shape of penes. The abdomens of $T$. xavantinensis and $T$. amanda are entirely dark brown as in $T$. regulus, Thraulodes liminaris and Thraulodes consortis. T. regulus, T. xavantinensis and $T$. amanda have costal and subcostal hyaline areas and one band on the femora, but the shape of penes is different. T. pelicanus will key to $T$. marreroi and T. osiris in Domínguez et al. (2006), but is easily distinguished from $T$. marreroi and $T$. osiris based on the genitalia, styliger plate with a posterior long projection plus a well-developed lateral pouch on the penes. The species from Costa Rica, T. sinuousus, possess a peculiar sinuous spine, while in other Thraulodes species the spines are straight and sometimes a little curved.

Acknowledgements. The first author was supported by São Paulo State Research Foundation (FAPESP Grant No. 05/53874-1) and Brazilian National Science Research Agency (CNPq), while completing the paper.

\section{References}

Domínguez E., Molineri C., Pescador M.L., Hubbard D.M. and Nieto C., 2006. Ephemeroptera of South America, Aquatic Biodiversity of Latin America (ABLA Series), SofiaMoscow, $646 \mathrm{p}$.

Eaton A.E., 1883-1888. A revisional monograph of recent Ephemeridae or mayflies. T. Linnean Soc. Lond., Second Series, Zool., 3, 1-352.

Edmunds G.F. Jr., 1950. Notes on Neotropical Ephemeroptera. I. New and little known Leptophlebiidae. Rev. Entomol. (Rio de Janeiro), 21(3), 551-554.

Gonçalvez I.G., Da-Silva E.R. and Nessimian J.L., 2010. A new species of Thraulodes Ulmer (Ephemeroptera: Leptophlebiidae) from Southeastern Brazil. Zootaxa, 2438, 61-68.

Kimmins D.E., 1934. Notes on the Ephemeroptera of the Godwin and Salvin collection, with descriptions of two new species. Ann. Mag. Nat. Hist., 14(1), 338-353.

Navás L., 1934. Insectos suramericanos. Novena [IX] serie. Rev. Real Acad. Cienc. Madrid, 31, 155-184.

Navás L., 1936. Insectos del Brazil. 5a Serie. Rev. Mus. Paul., 20, 731-734.

Nieto C. and Domínguez E., 2001. A new species of Thraulodes (Ephemeroptera: Leptophlebiidae) from Mexico. Aquat. Insect., 23, 63-66.

Thew T.B., 1960. Taxonomic studies on some Neotropical Leptophlebiid mayflies (Ephemeroptera: Leptophlebiidae). Pan-Pac Entomol., 36(3), 119-132.

Traver J.R., 1946. Notes on Neotropical Mayflies. Part I. Family Baetidae, Subfamily Leptophlebiinae. Rev. Entomol., 17, 418-436. 
Traver J.R. and Edmunds G.F. Jr., 1967. A revision of the genus Thraulodes (Ephemeroptera: Leptophlebiidae). Misc. Publ. Entomol. Soc. Am., 5, 349-395.

Ulmer G., 1920a. Neue Ephemeropteren. Arch. Naturgesch. (A) $85(11), 1-80$
Ulmer G., 1920b. Übersicht über die Gattungen der Ephemeropteren, nebst Bemerkungen über einzelne Arten. Stett. Ent. Zeit., 81(1-2), 97-144.

Ulmer G., 1943. Alte und neue Eintagsfliegen (Ephemeropteren) aus Süd- und Mittelamerika. Stett. Ent. Zeit., 104, 14-46. 